\title{
Dampak Dimensi Intellectual Capital Terhadap Knowledge Management Pendamping Desa di Kabupaten Kerinci
}

\author{
Ayu Esteka Sari, Salamah, Albetris \\ STIE Sakti Alam Kerinci \\ Fakultas Ekonomi Universitas Batanghari Jambi, Indonesia \\ Correspondence email: ayuesteka82@gmail.com \\ Email: salamah@gmail.com, \\ Email: albetris90@gmail.com
}

\begin{abstract}
In the context of realizing national development goals, the government is paying maximum attention to rural development. The great attention to the countryside is based on the fact that the village is home to a large part of the Indonesian people. The position of the village and the village community is the basis of the life of the nation and state of Indonesia. Intellectual capital is the main strength in an organization, which includes information, technical practitioners, expertise, intellectual property. Village assistance is carried out by village assistants whose job is to assist villages in the implementation of village development and village community empowerment. The objectives of village assistance include: 1) increasing the capacity, effectiveness and accountability of village governance and village development; 2) increase the initiative, awareness and participation of the village community in participatory village development; 3) increase the synergy of inter-sectoral Village development programs; and 4) optimizing village local assets in an emancipatory manner
\end{abstract}

Keyword: Human Capital, Social Capital, Organizational Capital, Intelectual Capital, Knowledge Management

\section{PENDAHULUAN}

Berdasarkan Undang-Undang Nomor 23 tahun 2014 tentang Pemerintahan Daerah, Desa sebagai kesatuan masyarakat hukum yang memiliki batas wilayah, yang berwewenang untuk mengatur dan mengurus kepentingan masyarakat setempat berdasarkan asal-usul dan adat- istiadat setempat yang diakui dan dihormati dalam sistem pemerintahan Negara Kesatuan Republik Indonesia. Untuk dapat mengembang amanat Undang-Undang penyelenggaraan pemerintah daerah tersebut, maka pemerintah membutuhkan dukungan dari aparatur pemerintah daerah yang tangguh, profesional dan mampu berbuat lokal serta bersaing secara global. Dalam rangka mewujudkan tujuan pembangunan nasional, pemerintah memberikan perhatian yang sebesar-besarnya pada pembangunan di pedesaan. Perhatian yang besar terhadap pedesaan itu didasarkan pada kenyataan bahwa desa merupakan tempat berdiamnya sebagian besar rakyat Indonesia. Kedudukan desa dan masyarakat desa merupakan dasar landasan kehidupan bangsa dan negara Indonesia.

Desa sebagai kesatuan masyarakat hukum terkecil yang memiliki batas-batas wilayah yang berwenang untuk mengatur dan mengurus kepentingan masyarakatnya berdasarkan asal- usul dan adatistiadat setempat yang diakui dan dihormati oleh negara. Pembangunan pedesaan selayaknya mengarah pada peningkatan kesejahteraan masyarakat pedesaan. Pemberdayaan masyarakat pedesaan dapat dilihat pula sebagai upaya mempercepat pembangunan pedesaan melalui penyediaan sarana dan prasarana untuk memberdayakan masyarakat, dan upaya mempercepat pembangunan ekonomi daerah yang efektif dan kokoh. Pembangunan pedesaan bersifat multi aspek, oleh karena itu perlu keterkaitan dengan bidang sektor dan aspek di luar pedesaan sehingga dapat menjadi pondasi yang kokoh bagi pembangunan nasional. Salah satu yang memiliki peran sentral dalam pembangunan desa adalah pendamping desa. Hal ini sebagaimana diatur dalam Peraturan Pemerintah Nomor 43 tahun 2014 tentang peraturan pelaksanaan Undang-Undang Nomor 6 Tahun 2014 tentang Desa yakni Pendamping desa bertugas memfasilitasi dan mendampingi masyarakat dalam penyelenggaraan pemerintahan desa, pelaksanaan pembangunan desa, pembinaan kemasyarakatan desa, dan pemberdayaan masyarakat desa. Tenaga pendamping bukanlah pengelola proyek pembangunan di desa. Kerja Pendampingan desa difokuskan pada upaya memberdayakan masyarakat desa melalui proses belajar sosial. Pendamping desa harus menjadi pelopor sekaligus motor penggerak pembangunan di desa. Pendamping desa bertujuan untuk mewujudkan desa yang mandiri, maju, dan sejahtera yang mampu mampu menjadi agen perubahan di setiap desa.

Sebagai salah satu pengawal implementasi UU Desa. Seorang Pendamping Desa harus memiliki pengetahuan, keterampilan dan sikap yang memadai untuk membantu pemerintah desa dalam 
penyelenggaraan pemerintahan dan pembangunan desa secara profesional, efektif dan efisien, akuntabel, terbuka dan bertanggungjawab. Untuk menciptakan pendamping desa yang menjadi ujung tombak program pemberdayaan potensi desa tersebut maka dibutuhkan pedamping desa yang memiliki Intellectual capital yang tinggi, yang lebih mengandalkan otak dan pengetahuan. Intellectual capital (IC) merupakan hasil dari penerapan pengembangan knowledge management (KM). Dengan kondisi yang demikian untuk menjawab tuntutan dari Tugas utama dan fungsi pendamping desa yang bisa memberdayakan warga desa dan melahirkan kader-kader pembangunan desa yang baru. Untuk menjalankannya, pendamping desa harus bias menjalankan fungsi-fungsi tersebut. Sehingga diharapkan mampu meningkatkan keunggulan berbasis knowledge management melalui intellectual capital sehingga menjadi keunggulan dan berhasil mencapai tujuan yaitu meningkatkan pembangunan dan pemberdayaan masyarakat desa. Atas dasar pemikiran diatas, tujuan penelitian ini adalah untuk mengetahui apakah variabel- variabel yang terkandung dalam intellectual capital yaitu human capital, social capital, dan organizational capital memiliki pengaruh positif terhadap knowledge management pendamping desa guna meningkatkan pembangunan desa dan pemberdayaan masyarakat desa di Kabupaten Kerinci

\section{Tinjauan Pustaka \\ Intellectual capital}

Istilah Intellectual capital pertama kali diciptakan oleh ekonom Galbraith yang menempatkan Intellectual capital dalam konteks mendapatkan keunggulan kompetitif (Chan, 2012). Intellectual capital adalah kekuatan utama dalam sebuah organisasi, yang mencakup informasi, praktisi teknik, keahlian, kekayaan intelektual bertujuan untuk menghasilkan laba. Bontis (2013) menunjukkan bahwa Intellectual capital adalah suatu sumber daya organisasi tidak berwujud, dan biasanya diklasifikasikan menjadi modal manusia (HC), modal struktural (SC) dan modal hubungan (CC). Intellectual capital adalah satu pengetahuan, informasi dan kekayaan intelektual yang mampu untuk menemukan peluang dan mengelola ancaman dalam kehidupan satu organisasi, sehingga dapat mempengaruhi daya tahan dan keunggulan bersaing dalam berbagai hal. Konsep triparti intellectual capital menunjukan bahwa meskipun individu yang menghasilkan, mempertahankan, dan menggunakan pengetahuan (human capital), pengetahuan ini dikembangkan melalui interaksi di antara mereka (social capital) untuk menghasilkan pengetahuan institusional yang dimiliki organisasi (organizational capital) Baron et al., (2013) dalam Katili et al (2016).

Menurut Baron et al., (2013) dalam Katili et al (2016) terdapat tiga unsur intellectual capital yang dapat diterjemahkan dalam tiga aspek pengukuran intangible assets yang terdiri dari human capital, social capital, dan organizational capital. Human capital merupakan kombinasi dari pengetahuan, keterampilan, inovasi dan kemampuan seseorang untuk menjalankan tugasnya sehingga dapat menciptakan suatu nilai untuk mencapai tujuan. Pembentukan nilai tambah yang dikontribusikan oleh human capital dalam menjalankan tugas dan pekerjaannya akan memberikan sustainable revenue di masa akan datang bagi suatu organisasi. Social capital dinyatakan dalam bentuk kesamaan keyakinan serta nilai-nilai dan hubungan sosial diantara anggota organisasi tidak seperti modal tak kasat mata yang lainnya social capital melekat dalam struktur hubungan antar pribadi dan juga diantara anggota organisasi. Organizational Capital mencakup setiap elemen struktur organisasi yang memfasilitasi kemampuan karyawan untuk menciptakan kekayaan bagi perusahaan dan stakeholder. Efektivitas proses ini sangat penting karena melibatkan prosedur internal yang memungkinkan untuk integrasi pengetahuan dan berbagi kemampuan yang menghasilkan penciptaan kekayaan bagi organisasi.

\section{Knowledge Management}

Tujuan Knowledge Management adalah untuk memaksimalkan keefektifan pengetahuan yang berhubungan dengan organisasi dan dari pengetahuan secara sistematis, eksplisit dan membangun, pembaruan dan aplikasi pengetahuan. Proses yang lebih berorientasi pandangan Knowledge Management yang diusulkan oleh Rastogi (2010) sebuah proses dan sistemastis secara terintegrasi, terkoordinasi dengan kegiatan untuk memperoleh, membuat, menyimpan, berbagi, menggunakan, mengembangkan, dan menyebarkan pengetahuan oleh individu dan kelompok dalam mencapai tujuan organisasi utama. Mempertimbangkan studi yang diusulkan oleh Alavi dan Leidner (2001), Gold et al. (2001), Lawson (2003) dan Heisig (2009) dalam Maria et al (2017), menyatakan empat kegiatan dari proses Knowledge 
Management yang luas:

1. Penciptaan pengetahuan

Mengacu pada upaya sadar untuk mencari dan mendefinisikan pengetahuan yang relevan dan sumbernya dari dalam dan luar organisasi. Proses ini berkaitan dengan kemampuan organisasi akuisisi untuk memperoleh dan mengumpulkan pengetahuan sebagai hasil dari proses kognitif individu dan interaksi sosial kolaboratif.

2. Penyimpanan pengetahuan

Pada tahap ini, penyimpanan dan mekanisme pengambilan dikembangkan untuk memungkinkan akses yang efektif dan cepat ke pengetahuan. Oleh karena itu, konsistensi pengetahuan sangat penting serta penggantian pengetahuan yang sudah ketinggalan zaman.

3. Transfer pengetahuan

Proses mentransfer pengetahuan yang dikodifikasi untuk memenuhi kebutuhan spesifik pengguna untuk pemanfaatan pengetahuan. Proses ini didorong oleh keberadaan saluran transmisi formal dan informal di berbagai tingkatan.

4. Aplikasi pengetahuan

Menunjukkan penggunaan pengetahuan dalam situasi baru di mana pengguna dapat belajar dan menghasilkan pengetahuan baru. Akibatnya, pada proses ini kecermatan pengetahuan melalui penerapannya ke aktivitas produktif Jawad (2012) berpendapat bahwa Knowledge Management menjadi perhatian penting bagi organisasi dalam beberapa tahun terakhir karena menawarkan banyak manfaat penting termasuk keunggulan kompetitif, peningkatan proses organisasi, peningkatan komunikasi, menghemat uang dan waktu organisasi yang meningkatkan produktivitas secara keseluruhan. Hari ini tanpa adanya Knowledge Management didalam organisasi membuat tidak dapat bertahan terhadap persaingan. Tahapan umum dari proses manajemen pengetahuan adalah seperti menyimpan, mengumpulkan, menyusun, berbagi, mengendalikan, menghasilkan, mendistribusikan, mengkodifikasi, menggunakan dan mengeksploitasi. Siklus Knowledge Management adalah proses berkelanjutan di mana informasi diidentifikasi, diperoleh, disempurnakan, dibagikan, digunakan, disimpan, dan didivestasi. Siklus Knowledge Management menyoroti bahwa bagaimana pengetahuan dikelola di lingkungan organisasi. Knowledge Management menawarkan beberapa manfaat utama bagi organisasi.

\section{Dampak Intellectual capital terhadap Knowledge Management}

Pengetahuan telah diidentifikasi sebagai sumber keunggulan kompetitif didalam sebuah organisasi dibandingkan dengan modal dan tenaga kerja sebagai kunci ekonomi sumber daya dalam bentuk aset tidak berwujud di negara maju. Oleh karena itu, Knowledge Management dalam organisasi harus dilakukan secara efektif dan cara yang efisien. Keuntungan penting dari Knowledge Management ada pada Intellectual capital sebagai sumber daya. Knowledge Management yang berbeda telah mengembangkan beberapa dimensi sumber daya yang telah dirangkum menjadi tiga jenis Intellectual capital yaitu modal manusia (HC), modal struktural (SC),dan modal hubungan. Manfaat dan kepentingan strategis Knowledge Management memberikan pengaruh kepada suatu organisasi untuk mengidentifikasi secara tepat jenis modal intelektual mana yang mereka bisa tingkatkan dan terapkan untuk mendapatkan keunggulan kompetitif yang berkelanjutan [Okunoye, 2004]. Knowledge Management sebagai proses dimana organisasi memperoleh kekayaan dari pengetahuan atau modal intelektualnya. Komponen-komponen Intellectual capital membentuk sumber daya pada Knowledge Management [Stewart, 1997], yang merupakan aset organisasi yang dapat digunakan untuk mencapai sasaran organisasi. Shahpasand (2013) menyatakan pengetahuan adalah sebagai sumber utama untuk inovasi dan produktivitas organisasi. Penerapan Knowledge Management akan mengarah pada pencapaian tujuan dalam Organisasi. Oleh karena itu, Knowledge Management sering dikenal sebagai sumber utama dalam organisasi. Selain itu, Intellectual capital adalah sebagai salah satu kemampuan organisasi yang penting yang dapat membantu organisasi untuk menciptakan pengetahuan dan manajemennya serta kompetitif secara berkelanjutan untuk Organisasi lain. Intellectual capital dapat dipengaruhi dalam Knowledge Management karyawan. 


\section{Peranan Pendampingan Desa Dalam Meningkatkan Pembangunan Desa Dan Pemberdayaan Masyarakat Desa}

Peraturan Menteri Desa, Pembangunan Daerah Tertinggal, dan Transmigrasi Republik Indonesia Nomor 3 Tahun 2015 tentang Pendampingan Desa, pasal 1 ayat (14) menyebutkan pendampingan desa adalah kegiatan untuk melakukan tindakan pemberdayaan masyarakat melalui asistensi, pengorganisasian, pengarahan, dan fasilitasi Desa. Pendampingan desa dilaksanakan oleh pendamping desa yang bertugas mendampingi desa dalam penyelenggaraan pembangunan desa dan pemberdayaan masyarakat desa. Tujuan pendampingan desa meliputi: 1) meningkatkan kapasitas, efektivitas dan akuntabilitas pemerintahan desa dan pembangunan Desa; 2) meningkatkan prakarsa, kesadaran dan partisipasi masyarakat Desa dalam pembangunan desa yang partisipatif; 3) meningkatkan sinergi program pembangunan Desa antarsektor; dan 4) mengoptimalkan aset lokal desa secara emansipatoris.

\section{METODE}

Penelitian ini dilaksanakan di Kabupaten Kerinci Propinsi Jambi. Waktu penelitian dimulai dari bulan April 2019 sampai bulan Desember 2019. Penelitian ini menggunakan pendekatan eksplanatori (explanatory research) karena bertujuan untuk menganalisis hubungan antar variabel dan menjelaskan pengaruh antar variabel intellectual capital yaitu human capital, social capital, dan organizational capital dan terhadap knowledge management pendamping desa guna meningkatkan pembangunan desa dan pemberdayaan masyarakat desa di Kabupaten Kerinci. Populasi adalah wilayah generalisasi yang terdiri atas objek atau subjek yang mempunyai kualitas dan karakteristik kemudian ditarik kesimpulan. Populasi dalam penelitian ini adalah seluruh pendamping desa di 16 kecamatan di Kabupaten Kerinci, yang terdiri atas: Pendamping Lokal Desa (PLD) yang berkedudukan di tingkat Desa dan Pendamping Desa (PD) yang berkedudukan di tingkat Kecamatan. Sehingga didapatkan jumlah responden adalah berjumlah 100 orang. Teknik sampling dalam penelitian ini adalah full sampling dimana seluruh populasi dijadikan sampel.

Penelitian ini menggunakan survey untuk mendapatkan data-data yang diperlukan. Cara yang digunakan adalah dengan wawancara (interview) dan menyebarkan daftar pertanyaan (questionaire) kepada responden. Data primer, yaitu data yang diperoleh dari penelitian langsung pada pendamping desa yang ada di Kabupaten Kerinci, dari kuesioner yang diberikan kepada para pendamping desa untuk mendapatkan gambaran kondisi sesungguhnya. Data Sekunder diperoleh dengan mengambil data dan dokumen, laporan tertulis yang diolah sesuai kebutuhan berupa gambaran umum dari pembanguan desa di Kabupaten Kerinci. Teknik Pengujian Model dalam penelitian ini menggunakan Stuctural Equation Model (SEM). SEM merupakan gabungan dua metode statistik yang terpisah yaitu analisis faktor (factor analysis) yang dikembangkan di ilmu psikologi dan psikometri serta model persamaan simultan (simultaneous equation modeling) yang dikembangkan di ekonometrika. Penelitian ini menggunakan AMOS versi 21.00 untuk menganalisis hubungan struktural model yang diusulkan Kesesuaian model dievaluasi melalui telaah terhadap berbagai kriteria goodness-of-fit. Beberapa indeks kesesuaian dan cut-off value-nya yang digunakan untuk menguji apakah sebuah model diterima atau ditolak. Penelitian membutuhkan suatu analisis data dan interpretasi yang akan digunakan untuk menjawab pertanyaan-pertanyaan penelitian untuk mengungkap fenomena sosial tertentu, sehingga analisis data adalah proses penyerdehanaan data ke dalam bentuk yang lebih mudah dibaca dan diinterpretasikan. Model penelitian yang akan digunakan dalam penelitian ini adalah model struktur berjenjang dan untuk menguji hipotesis yang diajukan digunakan teknik analisis SEM (Structural Equation Modelling). 


\section{HASIL}

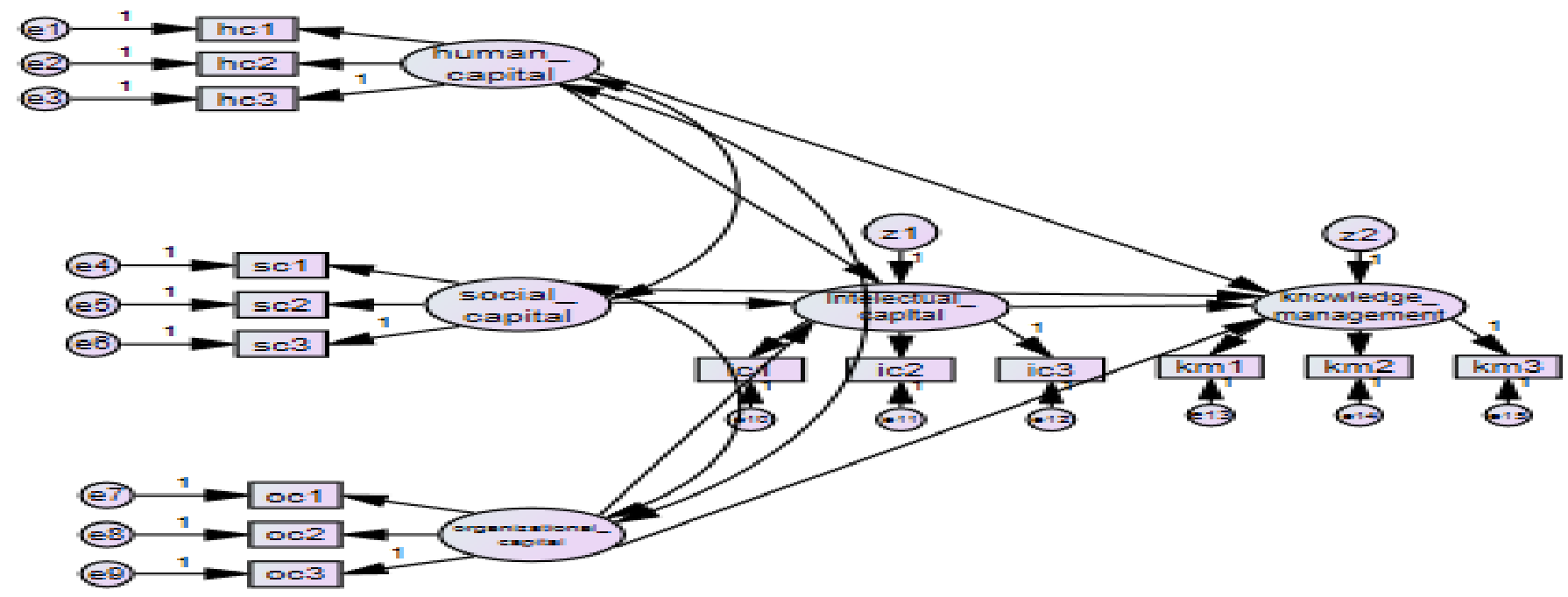

Gambar 1

Hasil Pengujian Full Model-Structural Equation Model (SEM)

\section{Pengujian Model Struktural}

Tabel 1

Hasil Pengujian Model

\begin{tabular}{|c|c|c|c|}
\hline No & Testing Fit & Hasil Uji Model & Tingkat Kecocokan Yang Bisa Diterima \\
\hline \multirow[t]{3}{*}{$\mathbf{1}$} & Absolute Fit Indices & & \\
\hline & DF & 80 & Diterima Jika Positif \\
\hline & $X 2 / \mathrm{DF}$ & 1,901 & Batas terendah 1,0 , batas tertinggi 2,03 \\
\hline \multirow[t]{5}{*}{2} & Icremental Fit Indices & & \\
\hline & - GFI & 0,848 & Nilai Berkisar 0-1, mendekati 1 semakin baik \\
\hline & - AGFI & 0,772 & \\
\hline & - TLI & 0,658 & \\
\hline & - CFI & 0,739 & \\
\hline \multirow[t]{3}{*}{3} & Icremental Fit Indices & 0,072 & $<0,08$ \\
\hline & - RMR & 0,075 & \\
\hline & - RMSEA & & \\
\hline \multirow[t]{3}{*}{4} & Parsimony Fit Indices & & \\
\hline & - PNFI & 0,458 & Nilai Berkisar 0-1 \\
\hline & - PCFI & 0,563 & \\
\hline
\end{tabular}

Sumber: data olahan

\section{Pengujian Hipotesis}

Pengujian koefisien hubungan antar variabel (path) menggunakan metode critical ratio. Nilai critical ratio untuk masing-masing koefisien path yang disyaratkan harus lebih besar atau sama dengan 1,96 atau tingkat signifikasi sebesar 5\%. Nilai koefisien path dan critical ratio per hubungan antar variabel dapat dilihat pada Tabel 2.

Tabel 2

Koefisien Path dan Critical Ratio Per Hubungan Antar Variabel

\begin{tabular}{lllrrrrr}
\hline & & & Estimate & S.E. & C.R. & P Label \\
\hline intelectual_capital & $<---$ & human_capital &, 561 &, 255 & 2,199 &, 028 & par_11 \\
intelectual_capital & $<---$ & social_capital &, 282 &, 058 & 4,878 & $* * *$ & par_12 \\
intelectual_capital & $<---$ & organizational_capital &, 002 &, 004 &, 464 &, 642 & par_13 \\
knowledge_management & $<---$ & intelectual_capital & 1,102 &, 298 & 3,701 & $* * *$ & par_14 \\
knowledge_management & $<---$ & human_capital &, 183 &, 293 &, 626 &, 531 & par_18 \\
knowledge__management & $<---$ & organizational_capital &, 295 &, 156 & 1,895 &, 058 & par_19 \\
knowledge__management & $<---$ & social_capital &, 001 &, 002 &, 348 &, 728 & par_20 \\
\hline
\end{tabular}

Sumber: data olahan 
Pengujian hipotesis dari koefisien hubungan antar variabel (path) menggunakan metode critical ratio. Nilai critical ratio (CR) untuk masing-masing koefisien path yang disyaratkan harus lebih besar atau sama dengan 1,96 atau tingkat signifikasi sebesar 5\% (Ghozali : 2007). Pada Tabel 2 dilihat bahwa pengujian hipotesis adalah :

\section{Pengujian Hipotesis 1}

Parameter estimasi hubungan antara human capital terhadap intelectual capital diperoleh sebesar 2,199. Pengujian hubungan kedua variabel tersebut menujukkan nilai C. $R=2,199$ dengan probabilitas $=0,028$ ( $\mathrm{p}<0,05$ ). Jadi, dapat diambil kesimpulan mengenai hipotesis 1 yang menyatakan bahwa human capital berpengaruh positif terhadap intelectual capital diterima. Hal tersebut disebabkan karena dari hasil pengolahan data menunjukkan nilai probability 0,028 memenuhi syarat $<0,05$ dan nilai C.R 2,199 juga memenuhi syarat $\geq \pm 1,96$.

\section{Pengujian Hipotesis 2}

Parameter estimasi hubungan antara social capital terhadap intelectual capital diperoleh sebesar 4,878. Pengujian hubungan kedua variabel tersebut menujukkan nilai C.R $=4,878$ dengan probabilitas $=0,000$ ( $\mathrm{p}<0,05$ ). Jadi, dapat diambil kesimpulan mengenai hipotesis 2 yang menyatakan bahwa social capital berpengaruh positif terhadap intelectual capital diterima. Hal tersebut disebabkan karena dari hasil pengolahan data menunjukkan nilai probability 0,000 memenuhi syarat $<0,05$ dan nilai C.R 4,878 juga memenuhi syarat $\geq \pm 1,96$.

\section{Pengujian Hipotesis 3}

Parameter estimasi hubungan antara organizational capital terhadap intelectual capital diperoleh sebesar 0,464. Pengujian hubungan kedua variabel tersebut menujukkan nilai C.R $=0,464$ dengan probabilitas $=$ $0,642$ ( $\mathrm{p}>0,05)$. Jadi, dapat diambil kesimpulan mengenai hipotesis 3 yang menyatakan bahwa organizational capital berpengaruh positif terhadap intelectual capital diterima tetapi tidak signifikan Hal tersebut disebabkan karena dari hasil pengolahan data menunjukkan nilai probability 0,642 tidak memenuhi syarat $<0,05$ dan nilai C.R 0,464 juga tidak memenuhi syarat $\leq \pm 1,96$.

\section{Pengujian Hipotesis 4}

Parameter estimasi hubungan antara intelectual capital terhadap knowledge management diperoleh sebesar 3,701. Pengujian hubungan keempat variabel tersebut menujukkan nilai C.R $=3,701$ dengan probabilitas $=0,000(\mathrm{p}<0,05)$. Jadi, dapat diambil kesimpulan mengenai hipotesis 4 yang menyatakan bahwa intelectual capital berpengaruh positif terhadap knowledge management diterima. Hal tersebut disebabkan karena dari hasil pengolahan data menunjukkan nilai probability 0,000 memenuhi syarat < 0,05 dan nilai C.R 3,701 juga memenuhi syarat $\geq \pm 1,96$.

Analisis pengaruh dilakukan untuk menganalisis pengaruh antar konstruk baik pengaruh yang langsung, tidak langsung, dan pengaruh totalnya. Efek langsung (direct effect) tidak lain adalah koefisien dari semua garis koefisien dengan anak panah satu ujung. Efek tidak langsung (indirect effect) adalah efek yang muncul melalui sebuah variabel antara. Efek total (total effect) adalah efek dari berbagai hubungan (Ghozali : 2006).

Tabel 3

Standardized Total Effects (Group number 1 - Default model)

\begin{tabular}{lrrrrrr}
\hline & $\begin{array}{r}\text { organizational_ } \\
\text { capital }\end{array}$ & $\begin{array}{r}\text { social_ } \\
\text { capital }\end{array}$ & $\begin{array}{r}\text { human__nital } \\
\text { capital }\end{array}$ & $\begin{array}{r}\text { intelectual_apital } \\
\text { canowledge_management }\end{array}$ & know \\
\hline intelectual_capital &,- 022 &, 016 &, 373 &, 000 &, 000 \\
knowledge_management &, 229 &, 020 &, 423 &, 875 &, 000 \\
\hline
\end{tabular}

Sumber: data olahan

Tabel 4

Standardized Direct Effects (Group number 1 - Default model)

\begin{tabular}{|c|c|c|c|c|c|}
\hline & $\begin{array}{r}\text { organizational_- } \\
\text { capital }\end{array}$ & $\begin{array}{l}\text { social_- } \\
\text { capital }\end{array}$ & $\begin{array}{r}\text { human_ } \\
\text { capital }\end{array}$ & $\begin{array}{r}\text { intelectual_- } \\
\text { capital }\end{array}$ & knowledge_management \\
\hline intelectual_capital &,- 022 &, 016 &, 373 &, 000 &, 000 \\
\hline knowledge_management & ,248 & ,006 & ,097 & ,875 &, 000 \\
\hline
\end{tabular}

Sumber: data olahan 
Tabel 5

Standardized Indirect Effects (Group number 1 - Default model)

\begin{tabular}{lrrrrrr}
\hline & $\begin{array}{r}\text { organizational_ } \\
\text { capital }\end{array}$ & $\begin{array}{r}\text { social_ } \\
\text { capital }\end{array}$ & $\begin{array}{r}\text { human__ } \\
\text { capital }\end{array}$ & $\begin{array}{r}\text { intelectual_zapital } \\
\text { canowledge_management }\end{array}$ & known \\
\hline intelectual_capital &, 000 &, 000 &, 000 &, 000 &, 000 \\
knowledge_management &,- 019 &, 014 &, 326 &, 000 &, 000 \\
\hline
\end{tabular}

Sumber: data olahan

Berdasarkan hasil dari tabel di atas maka perhitungan yang telah dilakukan dapat disimpulkan dalam matrik sebagai berikut :

Tabel 6

Koefisien Jalur Pengaruh Langsung, Pengaruh Tidak Langsung dan Total

\begin{tabular}{|c|c|c|c|}
\hline \multirow{3}{*}{ Uraian } & \multirow{2}{*}{\multicolumn{3}{|c|}{ Pengaruh }} \\
\hline & & & \\
\hline & Langsung & Tidak Langsung & Total \\
\hline Pengaruh Human Capital Terhadap knowledge management & ,097 & ,326 & ,423 \\
\hline Pengaruh Social Capital Terhadap knowledge management & ,006 & 014 & ,020 \\
\hline Pengaruh Organizational Capital Terhadap knowledge management & ,248 &,- 019 & 229 \\
\hline Pengaruh Intelectual Capital Terhadap knowledge management & ,875 &, 875 & ,875 \\
\hline
\end{tabular}

Sumber: data olahan

Hasil penelitian di atas dapat dimaknai bahwa :

1. Pengaruh langsung Human Capital terhadap knowledge management adalah 0,097. Sedangkan pengaruh tidak langsung Human Capital melalui intellectual capital terhadap knowledge management adalah 0,326. Artinya pengaruh langsung < pengaruh tidak langsung $(0,097<0,326)$. Maka disimpulkan bahwa intellectual capital merupakan variabel yang bisa memediasi Human Capital tehadap knowledge management pendamping desa di Kabupaten Kerinci, koefisien dari pengaruh tidak langsung lebih besar dibandingkan pengaruh langsung.

2. Pengaruh langsung Social Capital terhadap knowledge management adalah 0,006. Sedangkan pengaruh tidak langsung Social Capital melalui intellectual capital terhadap knowledge management adalah 0,014. Artinya pengaruh langsung < pengaruh tidaklangsung $(0,006<0,014)$. Maka disimpulkan bahwa intellectual capital merupakan variabel yang bisa memediasi social Capital tehadap knowledge management pendamping desa di Kabupaten Kerinci, koefisien dari pengaruh tidak langsung lebih besar dibandingkan pengaruh langsung.

3. Pengaruh langsung Organizational Capital terhadap knowledge management adalah 0,248. Sedangkan pengaruh tidak langsung Organizational Capital melalui intellectual capital terhadap knowledge management adalah -0,019 Artinya pengaruh langsung > pengaruh tidaklangsung $(0,248>-0,019)$. Maka disimpulkan bahwa intellectual capital merupakan variabel yang tidak bisa memediasi Organizational Capital tehadap knowledge management pendamping desa di Kabupaten Kerinci, koefisien dari pengaruh tidak langsung lebih kecil dibandingkan pengaruh langsung.

4. Pengaruh intellectual Capital terhadap knowledge management pendamping desa di Kabupaten Kerinci adalah 0,875 .

\section{SIMPULAN}

Penelitian ini menguji pengaruh dari Dampak Dimensi Intellectual Capital Terhadap Knowledge Management Pendamping Desa Di Kabupaten Kerinci. Dimensi Intellectual Capital yang terdiri atas tiga yaitu Human Capital, Social Capital dan Organizational capital. Dari ketiga dimensi tersebut didapatkan bahwa human capital dan social capital berpengaruh terhadap knowledge management melalui intellectual capital. Kedua dimensi tersebut sangat dibutuhkan dalam penerapan strategi-strategi dalam penerapan intellectual capital pendamping desa yang berdampak terhadap knowledge management pendamping desa di Kabupaten Kerinci. Human capital dan social capital merupakan hal yang penting dari intellectual capital terbukti memiliki pengaruh yang penting dalam penciptaan suatu prosedur dalam organisasi, SOP kerja serta aturan-aturan dan peraturan yang berlaku. Penelitian ini juga menguatkan bahwa seluruh dimensi intelectual 
capital

haruslah diintegrasikan menjadi satu untuk dapat meningkatkan knowledge management pada pendamping desa di Kabupaten Kerinci, dengan demikian untuk mencapai tujuan organisasi dan tercapainya perencanaan dari pendamping desa yaitu untuk meningkatkan pembangunan masyarakat desa dan meningkatkan pembangunan desa. Sesuai dengan yang telah diamanatkan oleh pemerintah yang tertuang di dalam Peraturan Pemerintah Nomor 43 tahun 2014 tentang peraturan pelaksanaan Undang-Undang Nomor 6 Tahun 2014 tentang Desa.

\section{DAFTAR PUSTAKA}

Chan, Kin Hang (2012) Exploring the Correlation Between Knowledge Management Maturity and Intellectual Capital Efficiency in Mainland Chinese Listed Companies. Journal of Information \& Knowledge Management, Vol. 11, No. 3 (2012) 1250017

Bontis, N (2013). Managing organizational knowledge by diagnosing intellectual capital: Framing and advancing the state of the eld. International Journal of Technology Management

Katili, Putiri B. (2016) Pengaruh Intellectual Capital Terhadap Kinerja Pegawai Seminar Nasional Sains dan Teknologi 20161 Fakultas Teknik Universitas Muhammadiyah Jakarta , 8 November 2016 TI - 024 p-ISSN : $2407-1846$

Rastogi, (2010). Knowledge management: Where did it come from and where will it go? Expert Systems with Applications, Special Issues on Knowledge Management, 13(1), 114.

Maria $t$ al (2017). The Role of Knowledge Management in Supply Chain Management: A Literature Review. Journal of Industrial Engineering and Management JIEM, 2017 - 10(4): 711-788 - Online ISSN: 2013-0953

Jawad Kayani (2012). The Analysis of Knowledge, Knowledge Management and Knowledge Management Cycles: A Broad Review International Journal of Academic Research in Economics and Management Sciences November 2012, Vol. 1, No. 6 ISSN: 2226-3624

Okunoye, A. (2004). Context-Aware Framework of Knowledge Management Cultural and Infrastructural Considerations. Rastogi, PN (2000). Knowledge management and intellectual capital — The new virtuous reality of competitiveness. Human Systems Management, 19(1), 3948.

Shahpasand, Mohammadreza (2013). The Effect of Intellectual Capital on Knowledge Management: Study on Agriculture Organization Experts in Kurdistan Province. International Journal of Business and Social Science Vol. 4 No. 12 [Special Issue - September 2013]

Sveiby, K (1997). The New Organizational Wealth: Managing and Measuring Knowledge-Based Assets. San Francisco: BerrettKoehler Publishers.

Santoso, S. 2012. Analisis SEM menggunakan AMOS. Jakarta : PT Elex Media Komputindo.

Ghozali, Imam. 2007. Konsep dan Alikasi Dengan Program Amos. Badan Penerbit UNDIP. 